\title{
CD4 + T-Lymphocytes cell counts in adults with human immunodeficiency virus infection at the medical department of a tertiary health institution in Nigeria
}

\author{
A. O. Ajayi, E. A. Ajayi, K. A. Fasakin ${ }^{1}$ \\ Departments of Medicine and ${ }^{1}$ Haematology, Federal Medical Centre, PMB 201, Ido-Ekiti, Nigeria
}

Correspondence to: Dr. A. O. Ajayi, Department of Medicine, Federal Medical Centre, PMB 201, Ido-Ekiti, Nigeria. E-mail: dejiajayi2@yahoo.co.uk

\begin{abstract}
Objectives: To evaluate the CD4+ cell counts in adults with human immunodeficiency virus (HIV) infections presenting at the medical department of the Federal Medical Centre, Ido-Ekiti, Nigeria.

Methods: This study was carried out at the medical department of the Federal Medical Centre (FMC), Ido-Ekiti, Nigeria, in the period July-December 2006. FMC, Ido, was recently upgraded to serve as the only center for HIV/AIDS referral, diagnosis and treatment in Ekiti State. The center offers free antiretroviral therapy.

All patients with a diagnosis of HIV/AIDS, either diagnosed at the center or referred from other hospitals, admitted to the medical department within the study period had their blood sample taken for CD4 cell counts estimation at the first visit to the center, as part of the routine workup to assess their disease status and need for antiretroviral therapy. Results: A total of 87 patients comprising of 54 (62.1\%) females and 33 (37.9\%) males had their CD4+ T-Lymphocytes cell counts evaluated within their first week of presentation. The total mean age of the population studied was $33.17 \pm 7.01$ years. The mean age of the females was $31 \pm 5.6$ years, while that of the males was $36.5 \pm 8.2$ years. The difference between the mean ages of females and males was statistically significant $(P=0.0004)$. The female: male ratio was 1.6:1. Out of the 87 patients, 30 were referrals from other hospitals within the state. The total mean CD4+ cell count was $230.7 \pm 311.9$ cells/ $\mu \mathrm{L}$. The mean CD4 cell count of females was $212.17 \pm 264.96$ cells/ $\mu \mathrm{L}$, while that of males was $261.0 \pm 389.19 \mathrm{cell} / \mu \mathrm{L}$. This difference was not significant $(P=0.4876)$. Majority of the patients (75, $[86.2 \%]$ ), had CD 4 cell count $<350$ cells/ $\mu \mathrm{L}$, comprising of 48 females and 27 males. Of the 75 patients, 57 ( $76 \%$ ) had a CD4 cell count $<200$ cells/ $\mu \mathrm{L}$ (33 females vs. 24 males).

Conclusion: At the time of HIV diagnosis, majority of our patients had a CD $4+$ cell count $<200 \mathrm{cells} / \mu \mathrm{L}$. This was consistent with a relatively advanced disease. More women than men in the population were found positive for HIV. More sustained and vigorous awareness campaigns need be embarked upon in the HIV propaganda in the Ekiti State on one hand and Nigeria on the other hand to bring down this Hydra-headed monster called HIV/AIDS.
\end{abstract}

Keywords: CD4+ T-lymphocyte cell count, HIV/AIDS infections, Tertiary health institution

\section{Résumé}

Objectif: Pour évaluer la cellule CD4+ chefs d'accusation chez les adultes avec human immunodeficiency virus (VIH) - infections présentant au département médical du centre médical fédéral, Ido-Ekiti, au Nigéria.

Méthode: Cette étude a eu lieu à le département médical de la fédérale Medical Centre (CSP), Ido-Ekiti, Nigeria entre les périodes d'étude de juillet-décembre 2006. CSP Ido a été récemment mis à niveau servir le seul centre pour le renvoi de VIH/SIDA, de diagnostic et de traitement de Ekiti-état. Le centre offre gratuitement des antirétroviraux. Tous les patients avec le diagnostic du VIH/SIDA, soit diagnostiqué au centre ou visé des autres hôpitaux au sein de la période d'étude pour le département médical avait leur sang. échantillon prélevé pour la cellule CD4 compte estimation à la première visite au centre, dans le cadre de la routine workup afin d'évaluer leur état de maladie et 
avez besoin pour traitement antirétroviral.

Results: Un total de 87 patients composé de 54 femelles (62.1\%) et les hommes (37, 9\%) 33. L'âge moyen total de la population étudiée était de $33.17 \pm 7.01$ ans. L'âge moyen des femmes était $31 \pm 5.6$ ans alors que des garçons était $36.5 \pm 8.2$ ans. L'âge moyen entre les femmes et hommes était statistiquement significatives $P=0.0004$. La femelle: mâle ratio était 1.6:1. Parmi les 87 patients, 30 étaient des renvois à d'autres hôpitaux au sein de l'état. La moyenne totale nombre de cellules CD4+ a été $230.7 \pm 311.9$ cellules/ $\mu$ l. Le nombre de cellules CD4 moyenne pour les femelles a été $212.17 \pm 264.96$ cellules/ $\mu \mathrm{l}$, tandis que celle de les mâles était $261.0 \pm 389.19$ cellules/ $\mu$ l. Cette différence n'était pas importante $P=0.4876$. Majorité des patients $[75,(86,2 \%)]$, avait CD4 cellule compter $<350$ cellules/ $\mu \mathrm{l}$ composé de 48 femmes et 27 hommes. Des 75 patients, 57 (76\%) avait un nombre de cellules CD4 $<200$ cellules/ $\mu$ l (33 femmes par rapport aux 24 hommes).

Page $\mid 258$ Conclusion: Au moment du VIH diagnostic, la majorité de nos patients avait une CD4+ cellule nombre $<200 / \mu$. Il s'agissait compatible avec une maladie relativement avancée. Plus de femmes que d'hommes dans la population ont été trouvés positifs pour le VIH. Sensibilisation plus vigoureuse et soutenue campagnes doivent être engagés dans la propagande du VIH dans l'état de Ekiti sur une seule main et le Nigeria d'autre part pour faire baisser ce monstre hydra-tête appelé VIH/SIDA.

Mots clés: Infections à VIH, CD4+ Nombre de cellules T-lymphocytes

DOI: $10.4103 / 1596-3519.59581$

\section{Introduction}

CD4+ Tlymphocyte cell count is a major indicator of the stage of the disease in human immunodeficiency virus (HIV)-infected individuals. ${ }^{[1,2]}$ Depletion of $\mathrm{CD} 4+\mathrm{T}$ cells is one of the hallmarks of progression of HIV infections. ${ }^{[3]}$ The absolute CD 4 cell count is used routinely in the evaluation and monitoring of HIV-infected persons..$^{[4]}$

CD4 cell counts have been found to have good correlation with development of various complications in HIV/AIDS. ${ }^{[5]}$ In general, patients with low CD4+ T cell counts have been infected with HIV for longer periods of time than have patients with higher CD4+ T cell counts. ${ }^{[6]}$ In this regard, it is clear that individuals who begin highly active antiretroviral therapy (HAART) when their CD $4+T$ cell counts are $<200$ cells $/ \mu \mathrm{L}$ have a significantly poorer response to therapy and a worse prognosis when compared with individuals who begin therapy when their CD4 $+\mathrm{T}$ cell counts are higher. ${ }^{[2,7-10]}$

CD4+ T-lymphocyte cell count is a standard test to stage HIV disease and to make therapeutic decisions regarding antiretroviral therapy and prophylaxis for opportunistic pathogens. ${ }^{[11]}$ It is also a relatively reliable indicator of prognosis, and it complements the viral load assay. These two assays independently predict clinical progression and survival. ${ }^{[1]}$

We carried out this study to determine at what stage in the disease HIV-infected persons present to our treatment facility, and to have a comparison with what is obtained in other centers.

\section{Materials and Methods}

This study was carried out at the medical department of the Federal Medical Centre (FMC), Ido-Ekiti, Nigeria, in the period July-December 2006. FMC, Ido, was recently upgraded to serve as a center for HIV/AIDS referral, diagnosis and treatment in Ekiti State. The center offers free antiretroviral therapy.

All patients with a diagnosis of HIV/AIDS, either diagnosed at the department or referred from other hospitals, admitted to the medical department within the study period had their blood sample taken for CD4 cell counts estimation at the first visit to the center, as part of the routine workup to assess their disease status and need for antiretroviral therapy.

CD4 cell counts were determined using a freshly taken blood sample drawn into a 2-mL Ethylene Diamine Tetra-acetic Acid (EDTA) anticoagulant bottle and processed within 2 hours of venesection. The samples were prepared and run on the Coulter Epics XL flow cytometer (Bechman Coulter Inc., Fullerton, California, USA) according to the manufacturer's instructions. The data generated were analyzed using the SPSS.

\section{Results}

A total of 87 patients comprising of 54 (62.1\%) females and $33(37.9 \%)$ males had their CD4+ cell counts evaluated within their first week of presentation. Of the 87 patients, 35 were referrals from other hospitals within the state. 
The overall mean age of the study population was $33.17 \pm 7.01$ years (range, 23-50 years). The mean age of the females in this study was $31 \pm 5.6$ years, while that of the males was $36.5 \pm 8.2$ years. The difference between the mean ages of females and males was statistically significant $(P=0.0004)$.

Majority $(51.7 \%)$ of the patients were in the age group 21-30 years. Females constituted a higher proportion in this age group (33 females as against 12 males); this difference was not statistically significant [Table 1].

The mean CD4+ T-Lymphocytes cell count of the study population was $230.7 \pm 311.9$ cells/ $\mu \mathrm{L}$. The mean CD4 cell count of females was $212.17 \pm 264.96$ cells $/ \mu \mathrm{L}$, while that of the males was $261 \pm 389.19$. Again, the difference here was not statistically significant $(P=0.4876)$. Majority $(86.2 \%)$ of the patients had their CD4 cell count $<350$ cells/ $\mu \mathrm{L}$. Fifty-seven $(65.5 \%)$ patients had their CD4 cell count $<200$ cells/ $\mu \mathrm{L}$ (33 females as against 24 males $)(P=0.3526)$. Only 9 patients had their CD4+ cell count $>500$ cells $/ \mu L$ [Table 2]. All patients with CD $4+$ cell count $<200$ cells $/ \mu \mathrm{L}$ were symptomatic at the time of presentation. In all, 13 patients were asymptomatic. It is interesting to know that 3 out of the 9 patients that had their CD $4+$ cell count $>500$ cells $/ \mu \mathrm{L}$ were symptomatic at the time of presentation. Majority $(75.8 \%)$ of the patients had a hemogram of $<10 \mathrm{~g} \%$.

\section{Discussion}

Current treatment guidelines recommend that therapy should be initiated when CD4+ T-lymphocyte count is $\leq 350$ cells/ $\mu \mathrm{L} \cdot{ }^{[12,13]}$ It had been reported that HIV-infected persons with lower CD4+ cell counts have been infected for longer periods of time as compared to those with higher CD4+ cell counts. ${ }^{[6]}$ Studies have reported that patients with CD4+ cell counts $<200$ cells $/ \mu \mathrm{L}$ have both a poorer response to HAART therapy

\begin{tabular}{|c|c|c|c|c|}
\hline Age range & Females & Males & Total & $\%$ \\
\hline $21-30$ & 33 & 12 & 45 & 51.7 \\
\hline $31-40$ & 18 & 12 & 30 & 34.5 \\
\hline $41-50$ & 3 & 9 & 12 & 13.8 \\
\hline Total & 54 & 33 & 87 & 100.0 \\
\hline \multicolumn{5}{|c|}{$\begin{array}{l}\text { Table 2: CD4 cell count distribution of the studied } \\
\text { population }\end{array}$} \\
\hline CD4 count & Females & Males & Total & $\%$ \\
\hline $1-<200$ & 33 & 24 & 57 & 65.5 \\
\hline $200-<350$ & 15 & 3 & 18 & 20.7 \\
\hline $350-<500$ & - & 3 & 3 & 3.4 \\
\hline$>500$ & 6 & 3 & 9 & 10.3 \\
\hline
\end{tabular}

and a worse prognosis than do individuals with higher CD4+ cell counts at the time of initiation of therapy. ${ }^{[2,13,14]}$

The present study showed that $86.2 \%$ of our patients had relatively advanced disease as reflected by their CD $4+$ cell counts of $<350$ cells $/ \mu \mathrm{L}$. Of particular interest is the fact that $65.5 \%$ of this studied population had a CD $4+$ cell count of $<200$ cells $/ \mu \mathrm{L}$ at the time of initial diagnosis. The figures obtained in this study were similar to those obtained in the studies by Kilaru et al. ${ }^{[11]}$ in Barbados and Guarner et al. ${ }^{[15]}$ in Mexico.

The results obtained in this study clearly showed that majority of the HIV-infected patients were diagnosed quite late in the course of HIV disease. The reasons for this observed delay are multifactorial. One is the level of denial among the individuals; the other factor may be the real or perceived social stigma toward HIV-infected persons and the fear of suffering discrimination in the society. Also, the hospital was recently upgraded as a referral center for diagnosis and treatment of HIV/AIDS; this may have encouraged patients with suspected infection to assess their disease status and seek treatment. Due to delayed presentation, most of our patients were in clinical categories $\mathrm{B}$ and $\mathrm{C}$ at the time of their presentation.

The individuals in this study with CD4+ cell count of $<200$ cells $/ \mu \mathrm{L}$ are at the risk of rapid disease progression and worse prognosis despite initiation of HAART therapy, based on current knowledge on HIV disease.

We also found that majority $(51.7 \%)$ of the patients in this study were in the age group 21-30 years, with the number of females (33) being more than that of males (12). This is similar to the findings by Kilaru et al., ${ }^{[11]}$ and in contrast to the Mexico findings. ${ }^{[15]}$ We also found in this present study that males had a higher CD $4+$ cell counts $(261 \pm 389.19)$ than their female counterparts $(212.17 \pm 264.96)$. This difference was not statistically significant.

\section{Conclusion}

At the time of HIV diagnosis, majority of our patients had a CD4+ cell count $<200$ cells/ $\mu \mathrm{L}$. This was consistent with a relatively advanced disease. More women than men in the study population were found positive for HIV. More sustained and vigorous awareness campaigns need to be undertaken in the HIV propaganda programs in the Ekiti State on one hand and Nigeria on the other hand to bring down this Hydra-headed monster called HIV/AIDS. 


\section{References}

1. Mellors JW, Munoz A, Giorgi JU, Margolick JB, Tassoni C], Gupta P, et al. Plasma viral load and CD4 + lymphocytes as prognostic makers of HIV- 1 infection. Ann Intern Med 1997;126:946-54.

2. Hogg RS, Yip B, Chank KJ, Wood E, Craib KJ, O'Shaughnessy MV, et al. Rates of disease progression by baseline CD4 cell count and viral load initiating triple drug therapy. JAMA 2001;286:2568-77.

Page $\mid 260$

3. Shearer WT, Rosenblatt HM, Schluchter MD, Mofenson LM, Denny TN. Immunologic targets of HIV infection:Tcells. Ann NY Acad Sci 1983;693:35-51.

4. Centers for Disease Control (CDC). Guidelines for prophylaxis against Pneumocystic carinii pneumonia for persons infected with HIV. MMWR Morb Mortal Wkly Rep 1989;38:S5-6.

5. Hanson DL, Chu SY, Farizo KM, Ward JW. Distribution of $\mathrm{CD} 4$ + Tlymphocytes at diagnosis of AIDS- defining and other HIV- related illnesses: The Adult and Adolescent Spectrum of HIV Disease Project Group. Arch Intern Med 1995;155:1537-42.

6. Stein DS, Korvick JA, Vermund SH. CD4+ lymphocyte cell enumeration for prediction of clinical course of HIV disease: A review. ] Infect Dis 1992;165:352-63.

7. Hammer SM, Squires KE, Hughes MD, Grimes JM, Demeter LM, Currier JS, et al. A controlled trial of two nucleoside analogues plus indinavir in persons with HIVinfection and CD 4 cell counts of 200 per cubic millimetre or less. N Engl ] Med 1997;337:725-33.

8. Chaisson RE, Keruly JC, Moore RD. Association of intial CD4 cell count and viral load with response to highly active antiretroviral therapy. JAMA 2000;284:3128-9.

9. Ledergerber B, Egger M, Opravil M, Telenti A, Hirschel B, Battegay $\mathrm{M}$, et al. Clinical progression and virological failure on HAART in HIV-1 patients: A prospective cohort study: Swiss HIV Cohort Study. Lancet 1999;353:863-8.

10. Hogg RS, Heath KV, Yip B, Craib KJ, O'Shaughnessy MV, Schechter MT, et al. Improved survival among HIVinfected individuals following initiation of HAART. JAMA 1998;279:450-4.

11. Kilaru KR, Kumar A, Sippy N. CD4 cell counts in adults with newly diagnosed Hiv infection in Barbados. Pan Am J Public Health 2004;16:302-7.

12. Yeni PG, Hammer SM, Carpenter CC, Cooper DA, Fischl MA, Gatell JM, et al. Antiretroviral treatment for adult HIV infection in 2002: Updated recommendation of the International AIDS Society. USA panel. JAMA 2002;288:222-35.

13. Sterling TR, Chaisson RE, Keruly ], Moore RD. Improved outcomes with earlier initiation of HAART among HIV infected patients who achieve durable virologic suppression: Longer follow-up of an observational cohort study. J Infect Dis 2003;188:1659-65.

14. Garcia F, De Lazzari E, Plana M, Castro P, Mestre G, Nomdedeu $\mathrm{M}$, et al. Long term $\mathrm{CD} 4+\mathrm{T}$-cell response to HAART according to baseline CD4 + t-cell count. ] Acquir Immue Defic SynDr. 2004;36:702-13.

15. Guarner ], Uribe-Zuniga P, Hermandez-Tepichin G, Terantoledo X, Del Rio C. Comparison of CD4+ T- cell counts in men and women recently diagnosed with HIV infection in Mexico City, Mexico. AIDS 1997;11:701-2.

Source of Support: Nil, Conflict of Interest: None declared. 